\title{
İl Düzeyinde Gerileme Süreci: Erzurum Örneği
}

\author{
Cevat GERNi' ${ }^{1}$ \\ Özge BUZDAĞLI ${ }^{2}$ \\ Ömer Selçuk EMSEN ${ }^{3}$
}

\begin{tabular}{lcc}
\hline $\begin{array}{c}\text { Geliş Tarihi/ Received } \\
13 / 06 / 2020\end{array}$ & Kabul Tarihi/ Accepted & Yayın Tarihi/ Published \\
$06 / 07 / 2020$ & $15 / 07 / 2020$ \\
\hline Citation/Atıf: Gerni, C. Buzdă̆ll, Ö. ve Emsen, Ö. S., (2020), Il Düzeyinde Gerileme Süreci: \\
$\begin{array}{l}\text { Erzurum Örneği, Atatürk Üniversitesi İktisadi ve İdari Bilimler Dergisi, 34(3): 1181-1206, DOI: } \\
\text { 10.16951/atauniiibd.752312 }\end{array}$
\end{tabular}

Öz: Bu çalışmada hemen her ülkenin büyüme/kalkınma sürecinde doğal ve/veya politik ekonomi tercihleri sonucu yaşanan bölgeler ve iller arası dengesizlikler Erzurum özelinde ele alınmış, yaşanan sosyo-ekonomik gerileme süreci Bursa ve Kocaeli illeri ile karşılaştırmalı olarak verilmiștir. Erzurum, XIX. yüzyılın sonu ve hatta I. Dünya Savaşına kadar ekonomik ve siyasal açıdan önemli bir merkez konumundayken savaş sonrası oluşan düzende genç cumhuriyetin Batı illeri merkezli kalkınma çabalarının bir yansıması olarak ekonomik düşüş yaşanmaya başlamıştır. Ancak, asıl düşüş 1979 'da İslam Cumhuriyeti kuran ve Irak ile savaşmaya başlayan İran'a uygulanan ambargo ile gerçekleşmiş ve bu da şehrin canlılı̆̆ını olumsuz yönde etkilemiştir. 24 Ocak 1980 Kararları ile politik iktisatta radikal dönüşüm ve 80'li yıllarda başlayan ayrılıkçı terör, Osmanlı'da üçüncü büyük gümrük kenti olan Erzurum'u hâlihazırda Türkiye'nin geri kalmış illeri seviyesine düşürmüştür. Bu gelişmelerin kaçınılmaz sonucu ortaya çıkan göç, aynı zamanda az gelişmişliği besleyen unsurlardan olmuştur. Çözüm arayışları içerisinde, kamunun genelde önemli bir ekonomik potansiyele sahip olan Doğuya ve özelde de Erzurum gibi kentlere ayırımc politikalar izlemesi ve kalkınmanın sanayileşme ile eş anlamlı olduğu gerçeği dikkate alınarak karşılaştırmalı üstünlük yapısına uygun sanayileşmeye ağırlık verilmesi gerektiği ileri sürülebilir. Aksi takdirde, Doğudaki merkez illerdeki boşalma, çevre illerde de boşalmayı tetikleyecek ve bu süreç Türkiye'nin Batısında kalabalıklaşmayı ve metropol maliyetleri arttıracaktır.

Anahtar Kelimeler: Az gelișmişlik, Kent ekonomileri, Erzurum

The Regression Process at the Province Level: Example of Erzurum

Abstract: Erzurum was an important economic and political center until the end of the 19 th century and even until the First World War. In the post-war order, the economic decline, which is a reflection of the young republic's development efforts based on Western provinces, has begun. However, the real decline occurred in 1979 with the embargo imposed on Iran, which established the Islamic Republic and started to fight Iraq, and these caused a blow to the vitality of the city. A radical transformation in political economics occurred with 24 January decisions and separatist terrorism have already reduced Erzurum, which is the third largest city of Ottoman

${ }^{I}$ Prof. Dr. Beykent Üniversitesi, İktisadi ve İdari Bilimler Fakültesi, İktisat Bölümü, https://orcid.org//0000-0002-0214-3879

${ }^{2}$ Dr. Ö̆gr. Üyesi Atatürk Üniversitesi, Iktisadi ve İdari Bilimler Fakültesi, İktisat Bölümü, https://orcid.org/0000-0002-2798-9889

${ }^{3}$ Prof. Dr. Atatürk Üniversitesi, İktisadi ve İdari Bilimler Fakültesi, İktisat Bölümü, https://orcid.org//0000-0002-1809-0513 


\section{Il Düzeyinde Gerileme Süreci: Erzurum Örneği}

customs, underdeveloped provincial level. Migration emerged as the inevitable consequence of all these factors has also been one of the elements that feeds the underdevelopment. This regression process is given in comparison with Bursa and Kocaeli provinces. In pursuit of a solution, the public should pursue discriminatory policies in the East and in particular in cities such as Erzurum and considering the fact that development is synonymous with industrialization, it can be argued that industrialization should be focused on in accordance with the comparative advantage structure. Otherwise, discharge in the central provinces in the East will trigger discharge in the provinces in the hinterland and this process will deepen the crowding that will keep the West from being livable.

Key words: Underdevelopment, Urban economies, Erzurum

\section{Background}

\section{EXTENDED SUMMARY}

Development differences between countries have been explained with the phenomenon of industrialization. Similarly, industrialization has a role in the emergence of development differences between regions and/or provinces of a country. Public investments in industrially viable regions create a cycle by making those regions or provinces attractive, receiving immigration, increasing rent, and increasing public spending again. This cycle ultimately deepens imbalances by creating development differences on a regional and provincial basis. The issues tried to be mentioned here were the factors that created a decline in Erzurum on a provincial basis and development in provinces such as Bursa and Kocaeli, which were established as an industrial center.

\section{Purpose}

The main motif of this study is the comparative analysis of Bursa and Kocaeli as the provinces in the West, which is still developing, and Erzurum as the example of the provinces in the East, which has declined.

\section{Method}

In the study, the shares of Bursa, Kocaeli and Erzurum in GDP, the number of enterprises in the manufacturing sectors, the total cultivated agricultural area, the numbers of bovine and ovine, the net migration numbers, the number of automobiles, the public income-expenditure rates are presented in tables. In addition, employment, population and consumption expenditures by sub-regions to which the provinces are connected are also analyzed with the help of tables.

\section{Findings}

While the shares of Bursa and Kocaeli from national income have increased over the years, it has been observed that Erzurum's share in national income is quite low and this is in the direction of decline. It is noteworthy that the number of entries in the manufacturing sector has increased in both Bursa and Kocaeli over the years, and that it has remained at the same point in Erzurum. In 2004-2018 period, employment rates increase in TR41, where Bursa is also located, and TR42, including Kocaeli, while employment rates are decreasing in TRA1 region, which also includes Erzurum. Although Erzurum has more cultivated areas than Bursa and Kocaeli, it has been observed that no 
added value can be produced due to this. In the period of 1975-2018, even though the number of net migrations decreased in Erzurum, it is a city that continues to migrate. On the other hand, Bursa and Kocaeli are cities receiving immigration.

\section{Conclusions}

Regarding the regions in which the decline continues, there is "an Eastern problem in general and Erzurum in particular". The increasingly deep regional imbalance problem caused by the wrong policies triggered the East to emerge and the West to become crowded. However, in the last 100 years correspond to the wrong public policies implemented in Turkey, will become the region's geopolitical position must have a role to date. The infrastructure investments that will create positive externalities, which can only be said as a precise requirement of the liberal state understanding, and both East-West and NorthSouth connections, both land and rail connections, need to be constructed in a healthy way.

One of the main policies that will prevent the East's ejaculation is the structuring that will connect the terrestrial crossing points with the sea. Therefore, rehabilitation of the current road, rail and airline will help this function, and it will be important to establish the Georgia-Iran connection between the speed-based mechanism, especially on the railway. In addition, industrialization and development does not occur without planning, on the contrary, planning has been liquidated in our country, thus the awareness of the "good state" and "good enterprise" has been lost. The liberation of the region will undoubtedly mean the liberation of the country; This is needed in order to "get out of the middle income trap and prevent crowding of the West". In the first place, with an input-output study that will reveal the advantages of the region, the areas that will have advantageous and revival effects can be identified and investments can be made in these areas.

\section{Giriş}

Ülkeler arasındaki farklılıkları zengin ve fakir şeklinde ele alan bakış açısının özellikle I. Dünya Savaşından sonra gelişmiş ve gelişmemiş şeklinde ele alınmaya başlaması (Dinler, 2005) ile birlikte kalkınma iktisadının da yükselişe geçtiği süreç başlamıştır. Zenginlik ölçütündeki bakış açısının kökeninde merkantilizm yatarken, gelişmişlik ölçütünün temelinde Sanayi Devrimi ve dolayısıyla sanayileşme yer almaktadır. Devrim ile birlikte kitlesel üretim ve buna paralel dış pazar arayışı aynı zamanda ithalat yapma gerekliliğini de besleyen unsur konumuna gelirken, bilinen merkantilist paradigmalar yerini klasik iktisadın liberal bakış açısına bırakmıştır. Sanayi Devrimi ile birlikte yaşanan teknolojik sıçrama maliyetlerde aşağı ve verimlilikte yukarı doğru etkiler doğurmuş (Güran, 2012: 134-135); statik toplumsal yapılar yerini dinamik yapılara bırakmış ve böylece Schumpeter'in yaratıcı yıkım kavramının niteliği daha iyi anlaşılır olmuştur (Acemoğlu ve 


\section{Il Düzeyinde Gerileme Süreci: Erzurum Örneği}

Robinson, 2014: 84; Pamuk, 2014: 84). Yaratıc1 yıkıma bağlı olarak ülkeler bazında ortaya çıkan farklılıkların zenginlik ile değil, sanayileşme ile açıklanabilirliği kalkınma iktisadının doğuşuna yol açan etkenler arasında yerini almıştır (Kaynak, 2011: 4).

Dünyada ülkeler arasında gelişmişlik farklılığının sanayileşme olgusu ile açıklanabilirliğine benzer şekilde bir ülkenin bölgeleri ve/veya illeri arasında da gelişmişlik farklılıkları gözlenmeye başlamıştır. Özellikle sanayiye uygun alan tespitine yönelik politikalara bağlı olarak; "uygun alanlara yönelik pozitif dışsallıklar yaratmaya yönelik kamu eliyle sosyal sermaye harcamaları o bölge ve kenti cazip hale getirmekte, cazip hale gelen bölge ve kent göç almakta, oralarda rantiye/şerefiye yükselmekte; göçe bağlı olarak sosyal sermaye harcamaları derinleşmekte, yine göç alımı ortaya çıkmakta, şerefiye yükselmekte...” Bu döngü en nihayetinde bölgesel ve il bazında gelişmiş̧lik farkları yaratarak, dengesizlikleri derinleştirmektedir. Burada belirtilmeye çalışılan hususlar il bazlı olarak Erzurum'da gerilemeyi ve buna karşılık olarak sanayi merkezi olarak tesis edilen Bursa ve Kocaeli gibi illerde gelişmeyi yaratan unsurlar olmuştur.

Tarihi kökeni itibarıyla Erzurum ili özellikle Doğu-Batı arasındaki ticarette karayolu taşımacılığında merkezi konumda olmuştur. "Tarihi ipek yolu" üzerinde bulunan il aynı zamanda Kuzey-Güney taşımacılığının da bir kavşak noktasında olması nedeniyle, başta ticaret olmak üzere, ticarete dayalı emtianın işlenmesini içeren el zanaatları ve tarım-hayvancılık açısından önemli bir merkez görevi üstlenmiştir. Özellikle I. Dünya Savaşının hemen öncesinde

“ilde bulunan 10'un üzerindeki konsolosluğun varlı̆̆ ” dikkat çekicidir. Konsolosluk sayısındaki fazlalık, "il nüfusunun homojen olmaktan uzak, heterojen bir yapıda olduğu”nun göstergesidir ki, bu da ildeki sosyo-ekonomik hayatın canlılığına işaret eder. Cumhuriyetin başlarından 1980'lere kadar Doğuda önemli bir merkez olma fonksiyonunu sürdüren il, Osmanlıdan devralınan bakış açısına paralel olarak devam ettirilen Cumhuriyetin Batı ağırlıklı sanayileşme politikalarına rağmen kısmen de olsa mevcut konumunu koruyabilmiştir. Mevcut konumunu korumada 1950'lerde yapılan 3 büyük kamu yatırımı; Et ve Balık Kurumu, Ilıca Şeker Fabrikası ve Atatürk Üniversitesi önemli roller üstlenmiştir. Ancak, 1980 öncesi durağan yap1 1980'lerden itibaren sosyo-ekonomik anlamda kan kaybetme/gerileme süreci olarak kendini hissettirir olmuştur.

1980 sonrası başlayan gerileme sürecinde beş ana unsurun önemli etkileri olduğu söylenebilir:

(i) 24 Ocak 1980 Kararları ile birlikte uygulamaya konulan "liberal ekonomi politikalart ilin kamu ilgisinden uzak bir süreci yaşaması"na yol açmıştır. Özellikle serbest piyasa ekonomisi mantığının işletilmeye başlanmasıyla birlikte olumsuz iklim ve coğrafi koşullar nedeniyle Doğunun “özel sektörü motive edecek teşviklerden trak; ayrım gözetmeyen kamu teşvik politikalar" bölgeyi girişimciler için cazip olmaktan uzak tutmuştur. Diğer 
taraftan kamunun üretim faaliyetlerinden çekilmeye başlamasıyla birlikte uygulanan özelleştirmelerin ise daha çok bölge gerçeğinden yoksun olmasının, kamu işletmelerine girdi sağlayan veya kamu çıktısından beslenen özel sektörü olumsuz yönde etkilediği dikkat çekmiştir. Bu noktada son Şeker Fabrikaları uygulamaları üzerinden bir değerlendirme yapılacak olduğunda, çiftçinin pancar ekimi ve tohum-gübre gibi girdi temini düşerken, pancarın küspesinin girdi olduğu hayvancılık sektörü de çıktı yönüyle bu durumdan olumsuz yönde etkilenmiştir.

(ii) 1979 İran İslam Devrimi ve devamında başta ABD olmak üzere Batı menşeli uygulanan ambargolar sonucunda Erzurum, Doğu-Batı ve KuzeyGüney "ticari kavşak olma özelliğini” kaybetmiş ve bunun sonucunda ticari gerileme lojistik kaybı ve buna bağlı olarak el zanaatlarına dayalı mamul işleme/imalat sanayi fonksiyonunun kaybını tetiklemiştir.

(iii) 1984 'de sivil-asker ayırt etmeksizin ayrılıkçı “terör örgütünün silahl eylemleri" başta Erzurum olmak üzere Bölge tarımını ve tarıma dayalı sanayiyi olumsuz yönde etkileyen öge olmuştur. Türkiye genelinde bölgesel dengesizlik denilince genelde Güney Doğu Anadolu Bölgesi anılırken, “asıl sorunun Doğu Sorunu olduğu dikkatlerden kaçmış"; bölge yeterli ilgiyi görememiş̧ir.

(iv) Erzurum'un iktisaden gerilemesi, çevre illeri de etkilemiş, ancak bu gerçeklik üzerine yoğunlaşmak yerine, şehre yapılması gereken kamu yatırımları politik mülahazalarla kenar illere kaydırılmaya başlanmıştır. Dolayısıyla, "bölge merkezi konumundaki kente akacak kaynakların yaratacağı taşma ve canlandırma etkileri ortaya çıkartılamamıştır.” Bölgesel iktisat literatüründe "kutuplaşma teorisi" olarak adlandırılan mekanizmada, bölge merkezinin gelişimi diğer küçük illeri de canlandırabilme etkisi doğurmaktadır ki, buna merkez İstanbul ve hinterlandı Kocaeli ve Tekirdağ, İzmir ve hinterlandı Manisa ya da merkez Ankara ve hinterlandı Çorum örnek teşkil etmektedir.

(v) Erzurum ilinin ekonomik gerileme süreci derinleşirken, "sanayi ve tarımdaki düşüş, dış ticareti de geriletmiştir”. Reel üretim olarak nitelendirilecek sanayi ve tarımdaki yetersizlikler "ili adeta hizmetler sektörü” odaklı bir hale getirmiştir. Sanayinin canlanma etkilerinden yoksunluk, il ekonomisini durağanlığa ve hatta gerilemeye götüren başlıca unsur olmuştur. Böylesi bir durumda, Türkiye ekonomisindeki büyüme ve canlanmanın etkilerinin il ekonomisine yansımaları “oldukça culız” kalmakta; buna karş1lık daralmalar il ekonomisinde "derin" bir şekilde hissedilmektedir.

İlin gerileme sürecinde 1980'lerdeki bu önemli beş unsur, adeta “doğduğu yerde doyamama” sorununu beraberinde getirmiş; her anlamda göç olgusu yaşanır olmuştur. Ortaya çıkan göç olgusu daha çok beşeri/entelektüel ve sermaye boyutunu içerdiğinden iş imkânlarının kaybolmasına paralel olarak mavi yakalı işgücü de ili terk etmeye başlamıştır. Ortaya çıkan nüfus azalışı; (a) üretim için sermaye ve işgücü kaybı anlamı taşırken, (b) talepte daralmaya bağlı 


\section{Il Düzeyinde Gerileme Süreci: Erzurum Örneği}

olarak piyasalarda durağanlığı derinleştirmiştir. Ekonominin arz ve talep boyutunda ortaya çıan bu iki olumsuz olgu ilin gerilemesini giderek derinleştirici unsurlar olmuştur. Göç veren il(ler)de ortaya çıkan bu iki temel olumsuzluğa karşılık göç alan il(ler)de kalabalıklaşmanın getirdiği trafik, asayiş, işsizlik vb. negatif dişsallıkların derinleşmesi de kaçınılmaz olmuştur.

Yukarıda özet olarak verilen gerileme sürecini besleyen unsurlar aşağıdaki bölümlerde daha ayrıntılı olarak irdelenecektir. Birinci kısımda, literatürde il ve bölge bazında dengesizlikleri inceleyen araştırmalara yer verilmiştir. İkinci kısımda kısaca Erzurum ekonomisinin tarihsel akışı özetlenmiştir. Üçüncü kısımda, kentin gerileme süreci mukayeseli olarak verilirken, belirli dönemler itibariyle GSYH değerleri, tarım ve hayvancılıktaki düşüş ve yansıması, göç olgusu istatistiklerle ortaya koyulmuştur. Özellikle liberal politika uygulamalarına bağlı olarak son dönemde ildeki gerilemenin daha belirgin bir şekilde yaşandığına temas edilecektir. Sonuç kısmında ise politika önerileri üretilmeye çalışılmıştır.

\section{2. İl ve Bölge Bazında Dengesizlikler Üzerine Literatür İncelemesi}

$\mathrm{Bu}$ çalışmanın ana motifi gelişmiş Batıdaki iller ile gerileyen Doğudaki il örneği olarak Erzurum'un karşılaştırmalı olarak incelenmesidir. Dolayısıyla konuyla ilgili literatür incelemeleri de bölgesel ve iller arası dengesizlikleri ve buna dayalı olarak ortaya çıkan etkileri incelerken, bu çalışmanın da motivasyonunu ve inceleme konusu yapılacak değişken/sektör seçimine yardımc1 olacağı düşünülebilir. Bu çerçevede özelde Erzurum ve genelde Türkiye bazında konuyla ilgili olarak bölge ve il bazlı dengesizlikler ile bunun yansıması olan göç üzerine yapılmış çalışmalar aşağıda özet olarak sunulmuştur.

Küçükoğlu (2005), 1995-2005 dönemindeki yatırım teşviklerini sektörel ve bölgesel açıdan incelemiş ve GAP bölgesinde uygulanan teşviklerin etkinliğini araştırmıştır. Sonuç olarak geniş kapsamlı ve dağınık olan vergi teşviklerinin denetlenememesi, bürokrasinin fazla olması ve sürekli değişen mevzuatın sistematik kayıt yapılmasına engel teşkil etmesi, söz konusu teşviklerin amacına uygun olarak değerlendirilememesine neden olduğunu belirtmiştir.

Sarı ve Güven (2007), Türkiye'de iller arası gelişmişlik farklılıklarını gidermek amacıyla başvurulan Kalkınma Öncelikli Yöreler (KÖY) uygulamasının etkisini 1970-1998 dönemi için genelleştirilmiş entropy ayrıştırma yöntemiyle analiz etmişlerdir. Elde edilen sonuçlara göre KÖY kapsamındaki iller ile kapsam dışındaki iller arasındaki gelir eşitsizliği zamanla artmakta, KÖY kapsamındaki ve kapsam dışındaki illerin kendi aralarındaki eşitsizliğin toplam eşitsizliğe etkisi ise zamanla değişiklik göstermemektedir. $\mathrm{Bu}$ sonuçlardan hareketle KÖY uygulamasının başarılı olamadı̆̆ını ifade etmişlerdir.

Başel (2007), Türkiye'de Cumhuriyet döneminden itibaren iç göçün nedenlerini araştırdığı çalışmasında, bölgesel dengesizliğin göçün en önemli 
nedeni olduğunu gözlemlemiştir. $\mathrm{Bu}$ sorunun giderilmesi için siyasal belirsizliklerin ortadan kaldırılması ve yatırımların çekilmesi için güvenilir bir ortamın oluşturulması gerektiğine vurgu yapmıştır.

Coşkun (2008), Erzurum'daki göç hareketliliğinin ülke içindeki dağglımını ve nedenlerini incelediği çalışmasında 2005 yılındaki göç istatistikleri ve nüfus sayım sonuçlarından yararlanmıştır. Erzurum'un 1975 'ten itibaren sürekli göç verdiği, başka illere göç etme sebepleri arasında en önemlisinin iş aramak olduğu ve diğer illerden gelen göçün temel nedeninin ise tayin ve eğitim olduğu sonucuna ulaşmıştır. Erzurum'un net göç veren bir il olma durumunun değiş̧irilebilmesi için hükümetlerin kente özel sanayi teşvikleri vermesinin yanı sıra kış turizminin canlandırılması ve termal turizmin ön plana çıkarılmasıyla ilin bölge çapında bir cazibe merkezine dönüştürülmesi yönünde önerilerde bulunmuştur.

Aydın (2008) çalışmasında Mardin ilini ele alarak bölgesel dengesizliğin giderilmesi amacıyla çeşitli önerilerde bulunmuştur. $\mathrm{Bu}$ öneriler arasında tarımda ürün çeşitliliğin arttırılarak ihracatın teşvik edilmesi, hayvancılığın geliştirilmesi, tarım kesimindeki küçük işletmelerin örgütlenerek pazarlık güçlerinin arttırılması, imalat sanayi sektörüne devlet teşviklerinin sağlanması, turizm potansiyelinin değerlendirilmesi, madenciliğe önem verilmesi ve sinır ticaretini kolaylaştıracak politikalar uygulanması yer almaktadır.

Karaalp ve Erdal (2009), Türkiye'de iller ve bölgeler arasında gelir farklılıklarının azalıp azalmadığını araştırmak amacıyla 1993-2001 dönemi için sigma yakınsama analizini kullanmışlardır. Elde edilen bulgulara göre söz konusu dönemde bölgeler arasında gelir farklılıkların azalmadığı, ülke genelinde bölgeler arası dengesizlik sorununun devam ettiği ancak iller arası gelir farklılıklarının azalma eğilimi gösterdiği ifade edilmiştir.

Çatal (2010), devlet teşviklerini Erzurum ili özelinde araştırdı̆̆ 1 çalışmasında Osmanlı döneminde Padişah IV. Mehmet (1642-1693) tarafından ilan edilen fermanla kalıcı olarak çeşitli vergi muafiyetleri sağlanan tek ilin Erzurum olduğunu tespit etmiştir. Bunun nedenini Erzurum'un zorlu iklim şartlarına ve merkeze uzak olmasına bağlayan yazar, Osmanlı döneminde bu imtiyazın tanındığı Erzurum'un, günümüzde devlet teşviklerinden en az yararlanan illerden biri olduğuna dikkat çekmiştir.

Şahin ve Uysal (2011), Türkiye'de yatırım teşviklerinin bölgesel dağglımındaki değişmeleri incelemek amacıyla 2002-2009 dönemi için shiftshare tekniğinden yararlanmışlardır. Elde edilen sonuçlara göre Doğu Anadolu Bölgesinin 2002-2008 döneminde enerji ve madencilik sektöründe yatırım teşvikleri aldığı, ancak enerji üreten yerine enerji tüketen bölge olması nedeniyle bölgesel dengesizliğin giderilmediği gözlenmiştir. Ayrıca incelenen dönemde Karadeniz Bölgesinin teşviklerden aldığı payın sürekli arttığı, bu teşviklerin özellikle enerji sektöründe yoğunlaştığ 1 ve emek-yoğun üretimlerde kullanılması nedeniyle istihdam artışı yarattığı dikkat çekmektedir. Güneydoğu Anadolu Bölgesinin yatırım teşviklerinden aldığı payın sürekli gerilediği, 


\section{Il Düzeyinde Gerileme Süreci: Erzurum Örneği}

dolaysıyla istihdam artışı yaratmadığı da elde edilen bulgular arasındadır. Özetle ele alınan dönemde verilen yatırım teşviklerinin bölgesel dengeleri gözetmediği söylenebilir.

Öztürk (2012), çalışmasında Türkiye'de bölgesel eşitsizliğin sektörel boyutlarını 1987-2001 dönemi için ayrıştırma yöntemiyle analiz etmiştir. Analiz sonuçlarında bölgesel eşitsizliğin en yüksek olduğu sektörün sanayi olduğu, hizmetler sektörünün ise bölgesel eşitsizliğin en önemli kaynağını oluşturduğu tespit edilirken, tarım sektörünün bölgesel eşitsizlikte önemli bir rolü bulunamamıștır.

Çatalbaş ve Yarar (2015), Türkiye'de bölgeler aras1 göçün belirleyicilerini 2008-2012 dönemi için panel veri yöntemiyle analiz ettikleri çalışmalarında, bölgenin zenginlik düzeyinin (kişi başı elektrik tüketim değerleri ile temsil edilmiş) iç göçü olumlu, enflasyon ve istihdam oranı ile terör sorununun ise iç göçü olumsuz etkilediği sonucuna varmışlardır. $\mathrm{Bu}$ sonuçlardan hareketle iç göçü tetikleyen en önemli nedenlerin sosyo-ekonomik faktörler ile güvenlik problemi olduğunu, bölgeler arasındaki gelir dağılımı dengesizliğinin giderilmesi ve güvenlik probleminin çözülmesiyle birlikte iç göçün neden olduğu çarpık kentleşme, yetersiz alt yapı, gecekondulaşma gibi sorunların zamanla azalacağına vurgu yapmışlardır.

Gerni vd. (2015) 2004-2012 dönemi için Türkiye'de 26 alt bölge ve 81 ili kapsayan bir yakınsama analizi yaparak, yatırım teşviklerinin bölgesel dengesizlikleri gidermede hedefe ne ölçüde ulaşıldığını araştırmışlardır. Analiz sonuçlarında 26 alt bölgenin bölgesel gelirlerinin gittikçe birbirine yaklaştı̆̆ (yakınsamanın olduğu) ve bölgesel dengesizliklerin azaldığı, ancak yatırım teşviklerinin bu yakınsama üzerinde olumlu bir etki yaratmadığı gözlenmiş̧tir. İl bazındaki analizlerde ise 2009-2012 dönemindeki teşviklerin, 2004-2008 dönemindeki teşviklerden daha etkin sonuçlar verdiği tespit edilmiştir. Bunun nedenini ise son dönemdeki teşviklerin illerin rekabet gücüne göre farklı şekilde düzenlenmesi olarak açıklamışlardır.

Recepoğlu ve Değer (2016), yatırım teşviklerinin Türkiye'nin 26 alt bölgesinde ekonomik büyüme üzerindeki etkilerini 2004-2011 dönemi için inceledikleri çalışmalarında teşviklerin uzun vadede az gelişmiş bölgelerin kalkınmasına olumlu katkılar sağladığı sonucuna varmışlardır. Bu nedenle bölgesel dengesizliklerin giderilmesinde teşviklerin yararlı olduğunu, dengesizliklerin azaltılması için teşviklerin amacına uygun olarak kullanılıp kullanılmadığının denetlenmesi gerektiğini belirtmişlerdir.

Günok (2018), bölgelerarası gelişmişlik farklarının Van ili özelinde işsizliğe yansımalarını ele aldığı çalışmasında işsizliğin Van'da Türkiye geneline göre daha yüksek düzeyde seyrettiğini, cesareti kırılan işçilerin Van'da genele göre daha fazla olduğunu, bu durumun da çocuk işçilerin sayısını ve kayıtdışı istihdamı arttırdığını gözlemlemiştir.

Küçükali (2018), çalışmasında Erzurum'daki akademisyenlerin ilden göç etme düşüncelerini Atatürk Üniversitesi'nde çalışan 197 öğretim üyesine anket 
yaparak araştırmıştır. Anket sonuçlarına göre gelecek 5 yıl içerisinde akademisyenlerin yaklaşık \%75'inin ilden göç etme niyetinde olup, bunun nedenleri arasında sosyo-ekonomik olanakların sınırlı olması, eğitim kurumlarındaki yetersizlik, ilin coğrafi konumu ve sert iklimi yer almaktadır.

Kaplan (2019), Türkiye'de 12 alt bölgede teşviklerin bölgesel dengesizlikleri gidermedeki etkinliğini 2004-2017 dönemi için incelemiş ve söz konusu dönemde uygulanan yatırım teşviklerinin bölgesel dengesizliği gidermede anlamlı bir etkisinin olmadığ 1 sonucuna varmıştır. Teşviklerin etkin olması için bölgesel özelliklerin dikkate alınması, şeffaf, denetlenebilir teşvik politikalarının uygulanması ve yatırımcılar için piyasaların güvenirliğinin sağlanması gerektiğine dikkat çekmiştir.

Literatürde bölgesel dengesizlikleri gidermek amacıyla verilen yatırım teşviklerini inceleyen çalışmalardan bazılarında söz konusu teşviklerin etkin olmadığ1 (Küçükoğlu, 2005; Sarı ve Güven, 2007; Şahin ve Uysal, 2011; Kaplan, 2019), bazılarında ise teşviklerin bölgesel dengesizlikleri azalttığı (Gerni vd., 2015; Recepoğlu ve Değer, 2016) sonucuna ulaşılmıştır. Sonuçlardaki bu farklılığın, ele alınan dönemlerin farklı olmasından kaynaklandığı söylenebilir. Bununla birlikte çalışmaların ortak yanı, teşviklerin denetlenebilir, şeffaf ve rekabet gücüne göre verilmesinin bölgesel dengesizlikleri gidermede daha etkili olacağına vurgu yapmalarıdır. İl bazında yapılan çalışmalarda (Aydın, 2008; Çatal, 2010; Günok, 2018) ise ele alınan illerin teşviklerden yeterince pay alamadıkları, bunun sonucunda işsizliğin ve diğer illere göç edenlerin sayısının arttığı tespit edilmiştir.

İç göçün nedenlerini araştıran çalışmaların (Başel, 2007; Coşkun, 2008; Çatalbaş ve Yarar, 2015; Küçükali, 2018) sonuçları değerlendirildiğinde bölgesel dengesizliğin neden olduğu sosyo-ekonomik faktörlerin ve güvenlik sorununun ön plana çıttı̆g gözlenmektedir.

Erzurum özelinde yapılan çalışmalarda (Coşkun, 2008; Çatal, 2010; Küçükali, 2018), ilin sürekli göç verdiği ve teşviklerin yetersiz olduğu vurgulanmış, Osmanlı döneminde önemli bir merkez olan ilin, günümüzde bu özelliğini yitirdiğine dikkat çekilmiştir.

\section{Tarihsel Süreçte Erzurum Ekonomisi}

İran ve Kafkasya'dan gelen yolların Akdeniz ve Karadeniz ile Batı'ya ulaşmak için çatallandığı noktada olan Erzurum ili, bu yönüyle jeopolitik bir öneme sahiptir. Osmanlı idaresine Kanuni Sultan Süleyman'ın İran seferi esnasında geçen ilin ilk etapta sancak ve sonrasında da beylerbeyliğine dönüştürülmesiyle ülke içerisindeki önemi daha da artmış ve Erzurum, Osmanlının doğudaki merkezi konumuna geçmiştir. Doğuda üstlendiği siyasal merkez olma fonksiyonuna paralel olarak ticaret açısından da konumunu pekiştiren il, İstanbul ve İzmir'den sonra en önemli gümrük merkezi haline gelmiş̧ir. 1865 'te Vilayetler Kanununun yürürlüğe girmesiyle birlikte de vilayet olarak teşkil etmiştir. Cumhuriyetin kuruluşuyla birlikte 491 sayılı 20 Nisan 


\section{Il Düzeyinde Gerileme Süreci: Erzurum Örneği}

1924 tarihli yasanın 89. maddesine göre yeniden düzenlenen idari teşkilat ile Erzurum Vilayeti kurulmuştur (Gerni vd., 1998).

Erzurum, kendi adını taşıyan ovanın güney kenarı ile Palandöken dağının eteklerinde kurulmuş bir kenttir. Şehri çepeçevre kuşatan Karga Pazarı, Palandöken ve Bingöl Dağları aynı zamanda hayvancılık için de olumlu zemin sağlamıştır. Tarih boyunca önemli bir hayvancılık merkezi olduğuna dair ibare, İbn el-Esir'in 1230'larda sadece Tebriz'e 20.000 civarında koyun gönderildiğine ilişkin ifadesinden anlaşılmaktadır. Benzer şekilde Marco Polo da şehirde hayvancılığa uygun geniş otlakların varlığına temas etmiştir. Ayrıca çok büyük ve güvenli bir kaleye sahip olması da ticari hayatın ilde canlı olmasını sağlayan unsur olmuştur. XVII. yüzyılın ortalarında Erzurum'u ziyaret eden Evliya Çelebi, şehir esnafının saraciye, ipekçilik, kuyumculuk, terzilik gibi sanatlarla meşgul olduklarını belirtmiş ve şehirde hem Doğulu hem de Batılı tüccarların bulunduğuna temas ederek heterojen bir yapının varlığına işaret etmiştir.

XIX. yüzyılın başlarında Erzurum, İran'dan Trabzon'a ve Halep'e uzanan yolların kesiştiği bir noktada 130.000 nüfuslu, oldukça hareketli ve zengin bir ticaret ve sanayi (dericilik, kürkçülük, dokumacılık, hayvan ürünleri) merkezi olarak dikkat çekmekteydi. Bunu destekleyecek şekilde Charles S. Hampson (1891) tarafindan kaleme alınan “Trade of Erzeroum" adlı belgede (örneğin 1889-1890 y1lları için Erzurum'daki İngiliz konsolosluğunun yazdığı raporda) ilin, özellikle İran ile ticarette önemli fonksiyonlar icra ettiğine değinilirken, başta tahıl ve koyun olmak üzere il ekonomisinde ihracatın giderek arttı̆̆ına temas edilmiştir. Benzer biçimde Ahmet Hamdi Tanpınarlar (2004)'ın “Beş Şehir" adlı kitabında 1855 'te 100.000 'i aşan nüfuslu bir şehir olan Erzurum'un ekonomik gelişmesi transit yol üzerinde bulunmasından kaynaklanan avantajı ile açıklanmıştır. I. Dünya Savaş1 öncesi 10 'un üzerinde ülke konsolosluğunun bulunması kentte ikamet edenlerin ve dolayısıyla nüfusun heterojen yapısı hakkında fikir vermektedir.

\section{Kentin Gerileme Süreci}

Türkiye'de bölgesel dengesizlikler sorununun kökeninde Osmanlının başta payitaht İstanbul olmak üzere belli başlı liman ve askeri merkez olma özelliğindeki kentleri ile bunların dışında yer alan diğer kentler şeklindeki ayırımla kendini gösterdiği söylenebilir. Gelişmişlik açısından ortaya çıkmış olan bu düalistik durum cumhuriyette devreye sokulan Planlı Sanayileşme Politikaları ile birlikte belirginleşir olmuştur. Şöyle ki, genç cumhuriyet de Osmanlı'nın İstanbul ve belli başlı liman ve askeri merkez öncelikli yapısını adeta sürdürür politikalar izlemiştir. Bu politikalarda şüphesiz sanayileşmede hem yı̆̆ılma ekonomileri hem de pozitif dışsallıklardan yararlanma motifinin etkili olduğu söylenebilir. Bu durum kentleşme oranı açısından değerlendirmeye alınacak olunursa, 1820 'de \%17 olan oran 1913'de ancak \%26 seviyesine gelebilmiştir (Pamuk, 2014). Dolayısıyla Osmanlının payitaht ve onun hinterlandı eksenli kamusal bakış açısının cumhuriyetle de sürdürüldüğü ve 24 
Ocak Kararları ile birlikte bunun daha da derinleştirildiği söylenebilir. $\mathrm{Bu}$ uygulamaların "kısmi sanayileşme ve paralelinde kentleşmenin genelde Batı ve özelde de Marmara Bölgesi orijinli yapısı" şüphesiz buraları daha cazip hale getirmiş; Doğu ise adeta kendi kaderine terk edilmiştir (Şahin, 2012). Dolayısıyla, Osmanlıdan alınan miras bağlamında Erzurum'un iktisadi açıdan gerileme süreci de buna bağlı olarak derinleşmeye devam etmektedir. İlin kendine özgü gerilemesine etki eden en önemli faktörlerin başında; “coğrafi keşifler” ile 93 harbi sonrasında Rusların yaptırdığ 1 “Çulfa-Tebriz-Bakü demiryolunun inşası" gelmektedir. Böylece Trabzon-Tebriz transit yolunun önceki önemi kaybolmuştur. Ayrıca tarih boyunca sınır özelliği ve buna bağlı olarak jeopolitik yönden kuruluşundan beri öneme sahip olması, "şehrin defalarca istilaya uğraması" na yol açmıştır. Bunlardan en önemlileri 1829, 1877-1878 ve 1915-1918 Rus işgalleri ile bu işgaller döneminde yaşanan Ermeni isyanları ve 1859 depremi gibi vakalardır. Bu olaylar son iki yüzyılda kentin ekonomik canlılığını sekteye uğratan etkenler olarak görülmüştür.

Birinci Dünya Savaşı sonrası büyük ve yıkık bir köyü andıran kentin nüfusu 20.000'lere kadar düşmüştür. Kurtuluş Savaşı ile 1918'de Rus ve Ermeniler Erzurum'dan çıkarıldıktan sonra kentte ticari hayat yeni bir boyut kazanmıştır. Savaş sonrası şehre dönen Erzurumlu tüccar ve işadamları ile İranlı tüccarlar kent ticaretinin canlanmasını sağlamışlardır. Ancak, umduğunu bulamayan İranlı tüccarlar 1930'lu yıllarda şehirden ayrılmışlardır.

1939'da Erzurum-Sivas demiryolunun aç1lması, 1944'te Toprak Mahsulleri Ofisi'nin, 1948'de Palandöken ve Aziziye Un Fabrikalarının, 1953 'te Et ve Balık Kurumu'nun, 1954'te Ilıca Şeker Fabrikasının, 1957'de Atatürk Üniversitesi'nin, 1966'da Havaalanının, 1969'da Erzurum Briket Fabrikasının, 1971'de Aşkale Çimento Fabrikasının, 1975'te Organize Sanayi Bölgesinin ve 1977 'de Ilıca Süt fabrikasının kurulmaları, şehrin ekonomisine hayatiyet kazandıran önemli faktörler olmuştur.

Ancak, 1980'lerden sonra uygulanan liberal politikalar, kentin 1920-1980 dönemindeki gelişme seyrini bozmuş, kentteki fiziki ve beşeri sermaye unsurları, kentleşme açısından altyapısını sağlamış bölgelere göç etmeye başlamıştır. Yukarıda da belirtildiği gibi, özellikle 1980 sonrası liberal politika uygulamaları görece cazip konumdaki Batıya kaynakların kaymasına yol açarken, giderek kalabalıklaşan Batıda kamunun zorunlu olarak yaptığı altyapı yatırımları da yine bu bölgede toprak rantını artırıcı bir fonksiyon görevi görmüştür. Bu noktada "kentlerin çekmesi” ile değil, adeta "kırsalın itmesi” ile ortaya çıkan kentleşme 1980'de \%36'ya, 2000'de \%57'ye 2010'da \%70'e (Şahin, 2012) ve 2017'de de \%75'e ulaşmıştır (World Bank, 2019). Batının şişkinliğine ve hatta obeziteleşmesine dayalı uygulamalara bağlı olarak Erzurum'un nispi olarak tekrar bir gerileme süreci içerisine girdiği görülmektedir. Özellikle son dönemdeki nispi gerileme sürecindeki derinleşmeyi Erzurum, Bursa ve Kocaeli ile karşılaştırmalı biçimde çeşitli göstergelerle ortaya koymak mümkündür. 


\section{Il Düzeyinde Gerileme Süreci: Erzurum Örneği}

\section{(i) GSYH'dan alınan pay azalmaktadır.}

Erzurum'un, çevresinde kendini ekonomik aç1dan besleyen gelişmiş şehirlerin bulunmaması, bilakis Erzurum'un, Doğu'da Ağrı, Iğdır ve Kars ile Batı'da Erzincan ve Bayburt gibi zayıf kentleri besleyen bir konuma sahip olması ekonomik gelişmesi önünde bir engel teşkil etmektedir. Bu açıdan bakıldığında, Bursa ve Kocaeli gibi kentlerin İstanbul'u hem besleyen hem de ondan beslenen konumda olmaları nedeniyle, Türkiye'nin milli gelirinden daha fazla pay aldıkları görülmektedir. Tablo 1 söz konusu kentler ile birlikte Erzurum'un milli gelirden aldıkları payları ortaya koymaktadır. Tablo 1'de 1987 bazlı ve 2009 bazlı GSYH değerleri verilmiştir. Veriler TUIK'in hesaplama yöntemi değişimi nedeniyle kesikli konumdadır.

Tablo 1: Bursa, Erzurum ve Kocaeli'nin Türkiye GSYH'si İçindeki Payları (Binde oran) (GSYH, 1987 ve 2009 Bazli)

\begin{tabular}{|c|c|c|c|}
\hline \multicolumn{4}{|c|}{ (GSYH, 1987 Bazlı) } \\
\hline Yillar & Bursa & Erzurum & Kocaeli \\
\hline 1987 & 37.19 & 6.78 & 44.63 \\
\hline 1988 & 40.54 & 6.40 & 45.51 \\
\hline 1989 & 40.49 & 6.06 & 44.98 \\
\hline 1990 & 41.16 & 6.57 & 43.36 \\
\hline 1991 & 39.78 & 6.88 & 44.99 \\
\hline 1992 & 40.79 & 6.87 & 46.73 \\
\hline 1993 & 42.97 & 6.80 & 46.97 \\
\hline 1994 & 40.19 & 6.45 & 49.08 \\
\hline 1995 & 40.95 & 6.38 & 49.56 \\
\hline 1996 & 37.86 & 6.01 & 45.43 \\
\hline 1997 & 35.30 & 6.11 & 48.49 \\
\hline 1998 & 36.62 & 6.29 & 44.68 \\
\hline 1999 & 36.50 & 7.12 & 42.17 \\
\hline 2000 & 36.76 & 6.88 & 45.46 \\
\hline 2001 & 36.49 & 6.83 & 51.34 \\
\hline \multicolumn{4}{|c|}{ (GSYH, 2009 Bazlı) } \\
\hline 2004 & 39.46 & 6.03 & 28.60 \\
\hline 2005 & 40.12 & 5.74 & 29.67 \\
\hline 2006 & 40.61 & 5.64 & 31.39 \\
\hline 2007 & 40.68 & 5.63 & 32.06 \\
\hline 2008 & 40.47 & 5.68 & 32.79 \\
\hline 2009 & 39.43 & 6.05 & 30.82 \\
\hline 2010 & 38.82 & 6.20 & 31.94 \\
\hline 2011 & 39.71 & 5.97 & 34.38 \\
\hline 2012 & 39.64 & 5.93 & 34.31 \\
\hline 2013 & 40.09 & 5.83 & 35.83 \\
\hline 2014 & 40.49 & 5.78 & 36.18 \\
\hline 2015 & 40.33 & 5.70 & 36.55 \\
\hline 2016 & 40.49 & 5.79 & 36.87 \\
\hline 2017 & 41.07 & 5.67 & 38.65 \\
\hline
\end{tabular}

Kaynak: TUIK 
Tablo 1'de görüldüğü üzere Erzurum'un GSYH içindeki payı 1987'de binde 6.78 iken, 2017'de bu oran binde 5,67'ye gerilemiştir. Bursa'nın GSYH içindeki payı ise 1987-2017 döneminde artış göstermiş; 1987'de binde 37.19'luk pay 2017 'de binde 41.07'ye yükselmiştir. Kocaeli'nin GSYH içindeki pay1 1987-2001 döneminde binde 44-51 arasında değişirken, 2004-2017 döneminde binde 28-38 arasında değişmektedir. Bursa ve Kocaeli ile karşılaştırıldığında, her iki ilin de GSYH'den aldığı paylar istikrarını korusa da, belirgin bir şekilde artış yönünde iken; Erzurum'un milli gelir içindeki payının oldukça düşük olduğu ve bunun da gerileme yönünde olduğu görülmektedir.

Bilindiği üzere kalkınma iktisadında "iktisadi gelişme ayn zamanda sanayileşme ile eşanlamlılık taşımaktadır”. Kalkınmanın gerçekleşebilirliğinin ekonomik büyüme ile birlikte sosyo-kültürel yapıda iyileşmeleri kuşattığı dikkate alındığında, ister ülkeler arası, ister bir ülkenin illeri veya bölgeleri arası karşılaştırmalarında kalkınmışlığı tetikleyen en önemli unsur sanayileşmedir. Ve Yaşar Kemal (2015)'in “koşulları değiştirmeden insanı değiştirmeye kalkmak bir ahmaklıktır, bir boş çabadır” ifadesinde, koşullar olarak sanayileşmeden/kentleşmeden bahsetmek gerekir. Dolayısıyla "sanayiye dayalt olmayan büyüme motifleri adeta suni refah artışı" olarak kendini göstermekte ve bu durum da sürdürülebilir olmaktan uzak kalmaktadır. Konuyla ilgili olarak dünya sanayileşme tarihi dikkat çekici gelişmeleri bünyesinde barındırmaktadır. Sanayileşmenin Gizli Tarihi adlı kitabında Ha-Joon Chang (2015), sanayileşmenin tesadüfi, liberal uygulamalara dayalı olmadığını ve sürekli devlet müdahaleleriyle gerçekleştiğine vurgu yaparken, buna örnek olarak İngiltere, Almanya, Japonya, ABD, G. Kore'yi vermektedir. Günümüzde sanayileşmiş ülkelerinin müdahalesiz/liberal politikaları savunan bakış açıları "merdiveni itme" olarak nitelendirilmekte; aksine toplumların liberal reçeteler ile değil, müdahaleci “merkantilist uygulamalar" ile kalkınacağına vurgu yapılmaktadır. Dünyadaki ülke deneyimlerini bir ülkenin bölge ve illeri bazında da düşünmek gerektiği artık yadsınamaz konumdadır. Liberal düşüncede geriden gelenlerin ilerideki ülkeleri takip ederek onların terk ettikleri alanlarda avantaj yakalayıp sanayileşeceği savı adeta boş bir avuntu niteliği taşımaktadır. Böyle olsaydı, 1980'de başlayan liberal uygulamalarla Marmara bölgesi taşma etkisi gösterip Doğunun da sanayileşmesi gerekecekti ki, hâlihazırda bu bakış açısı geçerlilik arz ettiği sürece, Doğunun daha çok beklemeye devam edeceği açıktır.

Tablo 2'de iş kayıtlarına göre girişim sayıları ve Tablo 3'te de bu üç ilin bulunduğu istatistiki bölge sınıflamasındaki istihdam oranları verilmiştir. 


\section{Il Düzeyinde Gerileme Süreci: Erzurum Örneği}

Tablo 2: Illerin Imalat Sektöründe İş Kayttlarına Göre Girişim Sayıları ve Türkiye İçindeki Payları (\%)

\begin{tabular}{|c|c|c|c|c|c|c|}
\hline Yıllar & Bursa & Pay (\%) & Kocaeli & Pay (\%) & Erzurum & Pay (\%) \\
\hline 2009 & 19340 & 5.14 & 7063 & 1.88 & 1696 & 0.45 \\
\hline 2010 & 19507 & 5.18 & 7147 & 1.90 & 1674 & 0.44 \\
\hline 2011 & 19739 & 5.19 & 7302 & 1.92 & 1700 & 0.45 \\
\hline 2012 & 20695 & 5.20 & 7718 & 1.94 & 1779 & 0.45 \\
\hline 2013 & 21395 & 5.28 & 8123 & 2.00 & 1809 & 0.45 \\
\hline 2014 & 21804 & 5.33 & 8470 & 2.07 & 1792 & 0.44 \\
\hline 2015 & 21964 & 5.33 & 8587 & 2.09 & 1757 & 0.43 \\
\hline 2016 & 22613 & 5.33 & 9018 & 2.13 & 1833 & 0.43 \\
\hline 2017 & 22948 & 5.35 & 9187 & 2.14 & 1917 & 0.45 \\
\hline
\end{tabular}

\section{Kaynak: TUIK}

Tablo 2'de girişim kayıtlarının hem Bursa hem de Kocaeli'de artış gösterdiği, Erzurum'da ise adeta aynı noktada kaldığı dikkat çekmektedir. 2009'dan 2017'ye girişim kayıt oranındaki artışlar Bursa, Kocaeli ve Erzurum'da sirasiyla \%18.7 (19340'dan 22948'e), \%30.1 (7063'den 9087'ye) ve \%13.0 (1696'dan 1917'ye) olarak gerçekleşmiştir.

Tablo 3: Alt Bölgeler İtibariyle Kurumsal Olmayan Nüfusun [15 ve Üzeri Yaş]] İstihdam Oranlarl (\%)

\begin{tabular}{|c|c|c|c|}
\hline Yıllar & $\begin{array}{c}\text { TR41 (Bursa, } \\
\text { Eskişehir, Bilecik) }\end{array}$ & $\begin{array}{c}\text { TR42 (Kocaeli, } \\
\text { Sakarya, Düzce, } \\
\text { Bolu, Yalova) }\end{array}$ & $\begin{array}{c}\text { TRA1 (Erzurum, } \\
\text { Erzincan, Bayburt) }\end{array}$ \\
\hline 2004 & 46,4 & 36,0 & 55,9 \\
\hline 2005 & 46,6 & 38,6 & 51,3 \\
\hline 2006 & 45,2 & 40,2 & 45,9 \\
\hline 2007 & 45,2 & 40,3 & 41,9 \\
\hline 2008 & 44,1 & 42,4 & 48,4 \\
\hline 2009 & 41,7 & 41,8 & 48,1 \\
\hline 2010 & 42,3 & 43,7 & 49,5 \\
\hline 2011 & 44,9 & 48,2 & 47,3 \\
\hline 2012 & 45,4 & 48,1 & 45,4 \\
\hline 2013 & 46,9 & 49,5 & 46,9 \\
\hline 2014 & 46,3 & 49,0 & 46,7 \\
\hline 2015 & 46,4 & 49,8 & 48,0 \\
\hline 2016 & 45,5 & 47,9 & 47,0 \\
\hline 2017 & 46,7 & 48,8 & 46,6 \\
\hline 2018 & 48,2 & 49,3 & 44,6 \\
\hline
\end{tabular}

Kaynak: TUIK

Diğer taraftan Tablo 3'ten de görüleceği gibi, Bursa'nın da içinde bulunduğu TR41 ile Kocaeli'nin de içinde bulunduğu TR42 bölgelerinde istihdam oranları artmakta ve buna karşılık Erzurum'un da içerisinde yer aldığı TRA1 bölgesinde istihdam oranları azalmakta ve dolayısıyla konunun tersten okunması halinde işsizlikte artışların varlığına işaret etmektedir. 
(ii) Tarım ve hayvancılı̆̆ın önemi azalmıştır.

Yukarıda "sanayisizlik ve istihdamsızlık" üzerine yoğunlaş1lırken, temelde üç sektörden birisinin yetersiz kaldığına, yani sanayisizliğin en belirgin özellik olduğuna vurgu yapılmıştır. Kalan iki sektörden birisi hizmetler ve diğeri de tarımdır. Aşağıda Tablo 4'te Bursa, Erzurum ve Kocaeli'nde toplam işlenen tarım alanları verilmiştir.

Tablo 4: Bursa, Erzurum ve Kocaeli'nde Toplam İşlenen Tarım Alanı (Hektar)

\begin{tabular}{|c|c|c|c|}
\hline Yıllar & Bursa & Kocaeli & Erzurum \\
\hline 2004 & 280.536 & 92.642 & 378.541 \\
\hline 2005 & 283.494 & 92.481 & 378.890 \\
\hline 2006 & 270.689 & 84.170 & 375.483 \\
\hline 2007 & 254.419 & 78.508 & 330.856 \\
\hline 2008 & 258.642 & 79.784 & 411.772 \\
\hline 2009 & 252.747 & 74.859 & 357.547 \\
\hline 2010 & 244.362 & 74.865 & 344.217 \\
\hline 2011 & 229.814 & 70.843 & 349.939 \\
\hline 2012 & 241.175 & 76.180 & 379.048 \\
\hline 2013 & 223.341 & 72.526 & 357.115 \\
\hline 2014 & 222.475 & 71.393 & 357.283 \\
\hline 2015 & 216.351 & 71.885 & 346.121 \\
\hline 2016 & 211.919 & 70.111 & 344.937 \\
\hline 2017 & 213.662 & 84.955 & 339.178 \\
\hline 2018 & 211.356 & 66.148 & 338.693 \\
\hline
\end{tabular}

Kaynak: TUIK

Tablo 4'e göre 2004'te Erzurum'da toplam işlenen tarım alanı 378.541 hektar iken, 2018'de 338.693 hektara düşmüsşür. Diğer taraftan Erzurum'un, Bursa ve Kocaeli'ye göre daha fazla işlenen tarım alanına sahip olmasına karşılık, bunun gereği katma değer üretilememekle (TUİK verilerine göre hektar başına tarım ve hayvancılık kenti olarak nitelendirilen Erzurum'da 2018 yılı itibarıyla bu sektörün hasılaya katkısı 3.185 .754 milyon TL iken, Bursa'da 6.087.275 TL'dir; ayrıca bkz. ERVAK, 1999: 4) birlikte, özellikle tarımsal teşviklerden kaynaklanan ekimden uzak toprakların ortaya çıkması kaçınılmaz hale gelmiştir.

Tablo 5 ve Tablo 6'da Bursa, Erzurum ve Kocaeli'nde büyükbaş ve küçükbaş hayvan sayıları yer almaktadır. 
Il Düzeyinde Gerileme Süreci: Erzurum Örneği

Tablo 5: Bursa, Erzurum ve Kocaeli'nde Büyükbaş Hayvan Saylsı (Baş)

\begin{tabular}{|c|c|c|c|}
\hline & Bursa & Kocaeli & Erzurum \\
\hline 2004 & 124.263 & 55.520 & 540.156 \\
\hline 2005 & 142.418 & 60.766 & 530.085 \\
\hline 2006 & 132.563 & 58.907 & 535.388 \\
\hline 2007 & 148.707 & 59.933 & 556.737 \\
\hline 2008 & 147.235 & 66.164 & 539.776 \\
\hline 2009 & 149.329 & 75.961 & 532.464 \\
\hline 2010 & 160.223 & 77.774 & 538.014 \\
\hline 2011 & 172.968 & 82.957 & 588.007 \\
\hline 2012 & 189.774 & 99.513 & 624.982 \\
\hline 2013 & 199.939 & 115.944 & 670.683 \\
\hline 2014 & 193.153 & 114.948 & 655.836 \\
\hline 2015 & 197.119 & 109.945 & 641.811 \\
\hline 2016 & 186.145 & 109.032 & 650.963 \\
\hline 2017 & 201.288 & 115.727 & 731.282 \\
\hline 2018 & 236.604 & 116.211 & 768.997 \\
\hline
\end{tabular}

Kaynak: TUIKK

Tablo 6: Bursa, Erzurum ve Kocaeli’nde Küçükbaş Hayvan Sayısı (Baş)

\begin{tabular}{|c|c|c|c|}
\hline & Bursa & Kocaeli & Erzurum \\
\hline 2004 & 263.769 & 52.129 & 849.146 \\
\hline 2005 & 293.599 & 54.010 & 818.972 \\
\hline 2006 & 303.794 & 49.872 & 829.547 \\
\hline 2007 & 310.692 & 48.421 & 760.008 \\
\hline 2008 & 270.227 & 49.040 & 651.253 \\
\hline 2009 & 293.814 & 35.535 & 402.656 \\
\hline 2010 & 329.837 & 56.601 & 496.350 \\
\hline 2011 & 376.531 & 63.784 & 562.242 \\
\hline 2012 & 423.968 & 89.047 & 574.213 \\
\hline 2013 & 442.013 & 97.291 & 629.065 \\
\hline 2014 & 465.345 & 110.904 & 717.843 \\
\hline 2015 & 458.823 & 102.757 & 790.467 \\
\hline 2016 & 441.859 & 101.005 & 705.953 \\
\hline 2017 & 472.467 & 103.506 & 714.229 \\
\hline 2018 & 523.198 & 98.680 & 746.733 \\
\hline
\end{tabular}

Kaynak: TUİK

Türkiye'nin sanayi kentleri konumunda bulunan Bursa ve Kocaeli hayvan popülasyonu açısından da avantajlı konumunu pekiştirmektedir. Çayır ve meralarının büyüklügü ile dikkat çeken bir il olan Erzurum'da büyük baş hayvan popülasyonu 2004-2018 aras1 dönemde \%42.4 artarken, bu oranlar Bursa ve Kocaeli için sirasıla \%90.4 ve \%109.3 olmuştur. Tablo 6'dan da görüldüğü gibi 2004-2018 döneminde Erzurum'da küçükbaş hayvan sayısı ise azalmıştır (\%12.1). Buna karşılık Bursa ve Kocaeli’de aynı dönemde küçükbaş hayvan sayısında artış (sırasıyla \%98.4 ve \%89.3) gözlenmiştir. Nüfusu ve 
kentleşme oranları artan Türkiye'de şüphesiz beslenme sorununun varlığı dikkat çekmeye başlamış; ancak Erzurum beslenmede "hayvan popülasyonu açısından gerilemiştir."

(iii) Erzurum göç veren bir kenttir.

Gerek sanayisizlik (TUIK verilerine göre Erzurum'da 2018 yılı itibarıyla GSYH 20.583.277 TL, Bursa'da 155.316.701 TL, Kocaeli'nde 120.367.106 TL'dir. Sanayinin payı ise bu üç ilde sırasıyla \%16.37, \%43.84 ve \%46.72'dir), gerekse tarımda yetkinsiz konuma düşen Erzurum için kaçınılmaz sonuç göç vermektir. "İstanbul'un taşı toprağı altın" deyişi aslında sadece İstanbul'un değil, Batı'nın taş1 toprağı altın şekline dönüşmüş̧; insanlar doğduğu yerde doyamayınca, kaçınılmaz biçimde Batıya göçe yönelmişlerdir. Dolayısıyla göç unsurunu “insanın güzele-güzelliğe yönelmesi”nin doğal bir sonucu olarak görmek gerekir. İş, eğitim ve sağlık koşullarının görece daha yüksek olduğu Batı göç almaya devam etmektedir. Aslında yine kalkınma iktisadının bir diğer boyutu olan; az gelişmiş ülke-bölge-ilde "yaşamanın ömür maliyeti" ortaya çıkmaktadır. Ortalama yaşam, gelişmiş yerlerde daha uzun, buna karşılık az gelişmiş yerlerde daha kısadır. Aslında Batı'da toprak rantının giderek derinleşmesini besleyen göç, "göç ile rant yükselişi ve bu da tekrardan göç sarmalını yaratmıştır”. Göç edenin Batıda ev, dükkân, arsa vb. gayrimenkul alması ile Doğu'da kalıp bu türden alımda bulunanlar mukayese edildiğinde, Doğu'dakinin bu alımları ile servet kaybına uğradığı dikkat çekmektedir. Alansal ekonominin kurucularından Von Thünen ile toprak rantını ortaya koyan David Ricardo'nun bakış açılarında bu mekanizmanın varlığına temas edilmiştir (Dinler, 2005: 11). Almanya'da bile konut sahipliği oranı \%52'lerde iken, Türkiye'de bu oranın \%68'lerde olması, konuyu özetler mahiyettedir (Yalçın, 2017: 255). Zira tasarrufların ve dolayısıyla yatırımların yetersiz olduğu bir ülkede kaynakların dayanaklı tüketim olarak ifade edilen inşaata-konuta yönelmesi büyümenin de suni kalmasına yol açan en büyük etkendir.

Tablo 7, 1975'den bu yana, Erzurum, Bursa ve Kocaeli illerinin net göç sayısını göstermektedir.

Tablo 7: Bursa, Erzurum ve Kocaeli'nin Dönemler Itibariyle Net Göç Sayısı

\begin{tabular}{|c|c|c|c|}
\hline & Bursa & Erzurum & Kocaeli \\
\hline $1975-1980$ & 58720 & -46093 & 53640 \\
\hline $1980-1985$ & 47434 & -48745 & 41287 \\
\hline $1985-1990$ & 83641 & -88298 & 83262 \\
\hline $1995-2000$ & 85325 & -46491 & 211 \\
\hline $2007-2008$ & 35594 & -24586 & 23018 \\
\hline $2008-2009$ & 10247 & -8851 & 12033 \\
\hline $2009-2010$ & 15420 & -12417 & 15124 \\
\hline $2010-2011$ & 15985 & -5880 & 13244 \\
\hline $2011-2012$ & 6216 & -10683 & 11405 \\
\hline $2012-2013$ & 13774 & -16599 & 16417 \\
\hline $2013-2014$ & 15690 & -17215 & 24637 \\
\hline
\end{tabular}


Tablo 7 Devamı: Bursa, Erzurum ve Kocaeli'nin Dönemler İtibariyle Net Göç

\begin{tabular}{|c|c|c|c|}
\multicolumn{5}{|c|}{ Saylst } \\
\hline $2014-2015$ & 19695 & -12179 & 30231 \\
\hline $2015-2016$ & 20646 & -9383 & 25123 \\
\hline $2016-2017$ & 21214 & -10734 & 27538 \\
\hline $2017-2018$ & 854 & -2930 & 487 \\
\hline $1975-2018$ & 448455 & -361074 & 377657 \\
\hline
\end{tabular}

Kaynak: TUIK

Tablo 7'de görüldüğü gibi 1975-2018 döneminde Erzurum'da net göç sayısı azalış gösterse de göç vermeye devam eden bir şehirdir. Buna karş1lık Bursa ve Kocaeli ise göç alan şehirlerdir. Göçün bir yansıması da illerin Ankara'daki temsil sayıları üzerine olmaktadır. Dolayısıyla "göçe bağlı olarak Erzurum'un milletvekilli sayıları düssmekte ve bu da yatırım yapma ve kamu hizmetinden yararlanma imkânlarını azaltmaktadır”. Konuyla ilgili olarak 2019 yılının ikinci yarısından itibaren THY'nin kente yönelik yaptığı sefer sayısındaki azalış ve uçak bilet fiyatlarında artış örnek olarak verilebilir ki, kış turizminin önemli merkezlerinden biri olan Erzurum'un hizmetler sektörünün önemli bir kalemi talep yetersizliği ile karşılaşabilecektir.

Göçün en fazla yoğunlaştığ illerden birisi İstanbul'dur. Gerçi son birkaç yıldır İstanbul bu özelliğini kaybetmiş olsa da, genel anlamda Batı'daki kentler göç almaya devam etmektedir.

Tablo 8: Bölgedeki İllere Ait Nüfusun İstanbul'daki Oranları

\begin{tabular}{|c|c|c|c|c|}
\hline Nispi Sırası & il & 2018 Nüfusu & İstanbul'da Yaşayan Nüfus & Oran (\%) \\
\hline $\mathbf{1 5}$ & Ardahan & 98907 & 251586 & $\mathbf{1 , 6 7}$ \\
\hline $\mathbf{3 7}$ & Bayburt & 82274 & 120996 & $\mathbf{0 , 8 0}$ \\
\hline $\mathbf{1 2}$ & Erzincan & 236034 & 304554 & $\mathbf{2 , 0 2}$ \\
\hline $\mathbf{5}$ & Giresun & 453912 & 484423 & $\mathbf{3 , 2 1}$ \\
\hline $\mathbf{3 3}$ & Gümüşane & 162748 & 138953 & $\mathbf{0 , 9 2}$ \\
\hline $\mathbf{1 3}$ & Rize & 348608 & 299810 & $\mathbf{1 , 9 9}$ \\
\hline $\mathbf{1 4}$ & Kars & 288878 & 293263 & $\mathbf{1 , 9 5}$ \\
\hline $\mathbf{4}$ & Ordu & 771932 & 505608 & $\mathbf{3 , 3 6}$ \\
\hline $\mathbf{1 0}$ & Trabzon & 807903 & 404579 & $\mathbf{2 , 6 9}$ \\
\hline $\mathbf{8}$ & Erzurum & 767848 & 421399 & $\mathbf{2 , 8 0}$ \\
\hline $\mathbf{4 8}$ & Iğdır & 197456 & 94757 & $\mathbf{0 , 6 3}$ \\
\hline $\mathbf{2 2}$ & Ağr1 & 539657 & 195467 & $\mathbf{1 , 3 0}$ \\
\hline
\end{tabular}

Kaynak: TUIK

Tablo 8'de İstanbul'da ikamet edenlerin nüfusa kayıtlı olduğu illere göre nüfusları ve bunların İstanbul nüfusu içindeki \% oranları verilmiştir. İstanbul'da ikamet edenler arasında \%3,36'lık pay ile Ordu 4.sırada yer alırken, 3,21'lik pay ile Giresun 5. Sirada, \%2,80'lik pay ile Erzurum 8. sirada bulunmaktadır.

Aşağıdaki tabloda nüfusun bölgesel dağılımları verilmiştir. 
Tablo 9: Bölge Nüfusunun Genel Nüfus İçindeki Payl

\begin{tabular}{|l|c|c|c|c|c|}
\hline Yıllar & TRA1/Türkiye & TRA2/Türkiye & TRA/Türkiye & TR9/ Türkiye & İstanbul/ Türkiye \\
\hline $\mathbf{1 9 8 0}$ & & & 4,69 & 6,43 & 10,61 \\
\hline $\mathbf{2 0 0 7}$ & 1,52 & 1,61 & 3,13 & 3,53 & 17,81 \\
\hline $\mathbf{2 0 0 8}$ & 1,48 & 1,59 & 3,08 & 3,51 & 17,75 \\
\hline $\mathbf{2 0 0 9}$ & 1,46 & 1,57 & 3,03 & 3,48 & 17,80 \\
\hline $\mathbf{2 0 1 0}$ & 1,45 & 1,54 & 2,99 & 3,41 & 17,98 \\
\hline $\mathbf{2 0 1 1}$ & 1,44 & 1,55 & 2,98 & 3,36 & 18,23 \\
\hline $\mathbf{2 0 1 2}$ & 1,42 & 1,53 & 2,94 & 3,37 & 18,32 \\
\hline $\mathbf{2 0 1 3}$ & 1,39 & 1,49 & 2,88 & 3,33 & 18,47 \\
\hline $\mathbf{2 0 1 4}$ & 1,37 & 1,47 & 2,84 & 3,30 & 18,50 \\
\hline $\mathbf{2 0 1 5}$ & 1,35 & 1,43 & 2,78 & 3,27 & 18,62 \\
\hline $\mathbf{2 0 1 6}$ & 1,35 & 1,41 & 2,76 & 3,31 & 18,55 \\
\hline $\mathbf{2 0 1 7}$ & 1,33 & 1,38 & 2,71 & 3,26 & 18,60 \\
\hline $\mathbf{2 0 1 8}$ & 1,32 & 1,37 & 2,70 & 3,32 & 18,37 \\
\hline
\end{tabular}

Kaynak: TUİK

Göçün bir yansıması olarak bölge nüfusunun toplam ülke nüfusu içerisindeki payı sürekli azalış göstermektedir. Bu durumu da Kuzey Doğu Anadolu (TRA) ve Doğu Karadeniz (TR9) bölge nüfusunun toplam ülke nüfusu içerisindeki paylarında sürekli azalıştan görmek mümkündür.

(iv) Gerilemenin yansımaları: Tüketimde ve otomotiv kullanımında azalış.

Genel olarak az gelişmişliğin hem sebebi hem de sonucu olan göç unsurunun yanı sıra enerji/elektrik tüketimi ve otomobil sayıları da gelişmişlik göstergesi olarak alınabilir (Nişancı ve Emsen, 2016). Tablo 10'da bu iki göstergeden otomobil sayıları sunulmuştur.

Tablo 10: Otomobil Saylları (2018)

\begin{tabular}{|c|c|c|c|}
\hline & Otomobil Sayısı & Nüfus & $\begin{array}{c}\text { 1000 Kişiye Düşen } \\
\text { Otomobil }\end{array}$ \\
\hline Bayburt & 6629 & 82274 & 80.57 \\
\hline Erzincan & 28207 & 236034 & 119.50 \\
\hline Erzurum & 59019 & 767848 & 76.86 \\
\hline TRA1 & $\mathbf{9 3 8 5 5}$ & $\mathbf{1 0 8 6 1 5 6}$ & $\mathbf{8 6 . 4 1}$ \\
\hline Ağr1 & 9746 & 539657 & 18.06 \\
\hline Kars & 11958 & 288878 & 41.39 \\
\hline Ardahan & 3904 & 98907 & 39.47 \\
\hline Iğdır & 6449 & 197456 & 32.66 \\
\hline TRA2 & $\mathbf{3 2 0 5 7}$ & $\mathbf{1 1 2 4 8 9 8}$ & $\mathbf{2 8 . 5 0}$ \\
\hline Artvin & 15801 & 174010 & 90.81 \\
\hline Giresun & 41850 & 453912 & 92.20 \\
\hline Gümüşhane & 10559 & 162748 & 64.88 \\
\hline Ordu & 72580 & 771932 & 94.02 \\
\hline Rize & 33888 & 348608 & 97.21 \\
\hline
\end{tabular}


Il Düzeyinde Gerileme Süreci: Erzurum Örneği

Tablo 10 Devamı: Otomobil Saylları (2018)

\begin{tabular}{|c|c|c|c|}
\hline Trabzon & 105354 & 807903 & 130.40 \\
\hline TR9 & $\mathbf{2 8 0 0 3 2}$ & $\mathbf{2 7 1 9 1 1 3}$ & $\mathbf{1 0 2 . 9 9}$ \\
\hline İstanbul & $\mathbf{2 8 8 7 5 8 1}$ & $\mathbf{1 5 0 6 7 7 2 4}$ & $\mathbf{1 9 1 . 6 4}$ \\
\hline Bilecik & 33418 & 223448 & 149.56 \\
\hline Bursa & 496501 & 2994521 & 165.80 \\
\hline Eskişehir & 166734 & 871187 & 191.39 \\
\hline TR41 & $\mathbf{6 9 6 6 5 3}$ & 4089156 & $\mathbf{1 7 0 . 3 7}$ \\
\hline Bolu & 56243 & 311810 & 180.38 \\
\hline Düzce & 56554 & 387844 & 145.82 \\
\hline Kocaeli & 232254 & 1906391 & 121.83 \\
\hline Sakarya & 146793 & 1010700 & 145.24 \\
\hline Yalova & 36101 & 262234 & 137.67 \\
\hline TR42 & $\mathbf{5 2 7 9 4 5}$ & 3878979 & $\mathbf{1 3 6 . 1 0}$ \\
\hline Türkiye & $\mathbf{1 2 3 9 8 1 9 0}$ & $\mathbf{8 2 . 0 0 3 . 8 8 2}$ & $\mathbf{1 5 1 . 1 9}$ \\
\hline
\end{tabular}

Kaynak: TUIK

Tablo 10'da görüldüğü gibi 1000 kişiye düşen otomobil sayısı Türkiye'de 151.19 ve İstanbul'da ise 191.64 'dür. Buna karşllık bölgedeki rakamlar özelde İstanbul'un ve genelde de Türkiye'nin oldukça altında olup TRA1, TRA2, ve TR9'da sirasiyla 86.41, 28.50 ve 102.99 olmuştur.

Diğer taraftan "gelir elde edici faaliyetlerde yetersizlik, gelirin tüketime kanalize edilecek kısmını azaltıcı rol oynamakta; ancak temel ihtiyaçlar karşılanabilmekte; tasarrufsuzluk ortaya çıkmakta ve bu da yatırımsızlığı doğurmaktadır". Tablo 11'de de tüketim harcamalarının bölgesel dağılımları sunulmuştur.

Tablo 11: Bölgesel Tüketim Harcamaları

\begin{tabular}{|c|c|c|c|}
\hline Bölgeler & $\mathbf{2 0 0 3}$ & $\mathbf{2 0 1 4}$ & $\mathbf{2 0 1 8}$ \\
\hline Akdeniz-TR6 & 12,1 & 12,0 & 11,2 \\
\hline Bat1 Anadolu-TR5 & 11,0 & 11,5 & 10,6 \\
\hline Bat1 Karadeniz-TR8 & 4,8 & 4,9 & 5,2 \\
\hline Bat1 Marmara-TR2 & 4,5 & 4,5 & 4,6 \\
\hline Doğu Karadeniz-TR9 & 4,0 & 2,7 & 3,2 \\
\hline Doğu Marmara-TR4 & 8,9 & 10,5 & 11,2 \\
\hline Ege-TR3 & 13,5 & 14,6 & 14,9 \\
\hline Güneydoğu Anadolu-TRC & 4,9 & 5,8 & 6,1 \\
\hline İstanbul-TR1 & 25,9 & 24,5 & 24,4 \\
\hline Kuzeydoğu Anadolu-TRA & 2,3 & 1,9 & 1,7 \\
\hline Orta Anadolu-TR7 & 4,8 & 4,2 & 4,1 \\
\hline Ortadoğu Anadolu-TRB & 3,4 & 3,0 & 2,9 \\
\hline TOPLAM & 100 & 100 & 100 \\
\hline
\end{tabular}

Kaynak: TUIK

Toplam nüfusun \%18.37'sini barından İstanbul toplam tüketimin ise $\% 24,4$ 'ünü yapmaktadır. TRA bölgesinin toplam nüfusun $\% 2,70$ 'ini bünyesinde tutmasına karşılık toplam tüketim harcamasındaki payı \%1,7; TR9'un ise 
nüfusta payı $\% 3,32$ ve harcamadaki pay1 ise $\% 3,2$ 'dir. Ortalama tüketim yeteneği açısından her iki bölgenin de nüfus payının altında kalması gelir dağılımı açısından adaletsizliğin de bir yansıması olduğuna işaret etmektedir. Düşük gelir ve bir de bunun adaletsiz dağılımına ilave olarak ortaya çıkan sanayisizlik yapısıyla birlikte üretimsizlik-gelirsizlik, yaşam standartlarında düşüklük, kenti “mutluluk endeksi”nde ortalamanın altında tutan unsurlardan olmaktadır (Bkz. TUIKK).

(v) Kamu gelir-gider oranları sorgulanmaya değerdir.

Kişi başı değerler itibariyle bölgesel açıdan kamu harcamalarından alınan payların az gelişmiş bölgelerde daha yüksek olduğu dikkat çekmektedir. Ancak, nispeten gelişmiş Batı bölgelerinde kamu harcamalarının özellikle yatırım harcamaları boyutunun kümülatif etkileri dikkate alındığında, bunun daha fazla ölçek ve rant ekonomileri doğurduğu açıktır. Üretimsizlik ve göçün yansıması düşük gelir ve düşük vergi sarmalını doğurmakta ve bu da her iki bölgenin kamu gelirleri içerisindeki payının sürekli olarak azalışından anlaşılmaktadır.

Tablo 12'de 1995-2018 zaman aralığında il bazında kamu gelir-gider oranlarından da görmek mümkündür.

Tablo 12: Illerin Kamu Gelir - Gider Oranları (\%)

\begin{tabular}{|c|c|c|c|c|c|c|}
\hline & $\mathbf{1 9 9 5}$ & $\mathbf{2 0 0 0}$ & $\mathbf{2 0 0 6}$ & $\mathbf{2 0 1 0}$ & $\mathbf{2 0 1 5}$ & $\mathbf{2 0 1 8}$ \\
\hline Bayburt & 20.86 & 16.57 & 24.13 & 18.04 & 17.37 & 20.59 \\
\hline Erzincan & 28.15 & 23.22 & 30.68 & 24.55 & 25.46 & 25.12 \\
\hline Erzurum & 22.54 & 18.42 & 28.58 & 26.41 & 26.81 & 24.48 \\
\hline Ăgrı & 20.25 & 29.43 & 22.27 & 17.49 & 21.17 & 19.85 \\
\hline Kars & 16.35 & 15.41 & 24.42 & 19.87 & 16.64 & 16.43 \\
\hline Ardahan & 13.16 & 21.10 & 19.74 & 17.44 & 16.55 & 20.51 \\
\hline Iğdır & 18.37 & 45.19 & 24.81 & 19.60 & 15.41 & 26.34 \\
\hline Artvin & 50.12 & 38.70 & 44.62 & 39.31 & 31.15 & 35.21 \\
\hline Giresun & 61.58 & 43.98 & 42.27 & 36.30 & 32.72 & 34.69 \\
\hline Gümüşhane & 24.76 & 20.54 & 25.46 & 19.77 & 23.04 & 26.76 \\
\hline Ordu & 66.61 & 51.70 & 73.08 & 46.79 & 44.91 & 45.40 \\
\hline Rize & 99.54 & 89.73 & 99.24 & 80.36 & 71.39 & 95.34 \\
\hline Trabzon & 40.66 & 33.99 & 56.58 & 48.72 & 35.80 & 43.79 \\
\hline İstanbul & 399.24 & 488.09 & 926.29 & 819.65 & 789.03 & 778.22 \\
\hline Bilecik & 93.15 & 57.54 & 67.57 & 48.48 & 48.24 & 43.67 \\
\hline Bursa & 206.50 & 181.24 & 227.26 & 183.51 & 164.08 & 177.33 \\
\hline Eskişehir & 71.13 & 56.71 & 105.72 & 82.80 & 64.47 & 61.08 \\
\hline Bolu & 90.00 & 28.49 & 75.85 & 61.40 & 49.12 & 57.63 \\
\hline Düzce & - & 34.52 & 77.67 & 55.64 & 64.63 & 62.89 \\
\hline Kocaeli & 1103.73 & 1233.08 & 1467.86 & 1205.94 & 1055.69 & 1050.43 \\
\hline Sakarya & 75.80 & 35.61 & 61.59 & 57.06 & 71.16 & 34.50 \\
\hline Yalova & 164.59 & 119.84 & 177.57 & 84.01 & 96.11 & 123.24 \\
\hline Türkiye & 81.73 & 71.60 & 96.70 & 85.66 & 94.88 & 90.98 \\
\hline Kaynak: TUiK & & & & & &
\end{tabular}

Kaynak: TUİK 


\section{Il Düzeyinde Gerileme Süreci: Erzurum Örneği}

Kamunun daha az gelir toplayıp daha çok harcama yapısıında gelir yetersizliğinin kamu gelirlerini azalttığına işaret ettiğine temas edilmişti. Harcama kalemleri açısından da özellikle güvenlik açığının önemli bir harcama kalemi olduğu söylenebilir. Diğer taraftan güvenlik harcamaları dahil kamu harcamalarının bir tür Batıdan Doğuya "kamu kaynak transferi” yapıldığına ve böylece canlılığın sağlandığına vurgu yapılabilir. Doğuya kamu eliyle yüksek kaynak transferi yapılmasına rağmen gerileme sürecinin devam etmesi, "kamu harcamalarının bir tür sosyal transfer harcaması niteliği taşıdı̆̆g”; gerçek anlamda "üretken alanlar yaratmaktan uzak olduğ " anlamına gelmektedir.

Aslında bütün bu tablolardan Erzurum'un gerileme sürecini en özet şekilde milletvekili sayılarından görmek mümkündür. Zira gerileme ile birlikte göç kaçınılmaz hale gelmekte ve bu da milletvekili sayısında düşüş şeklinde yansimalar yaratmaktadır.

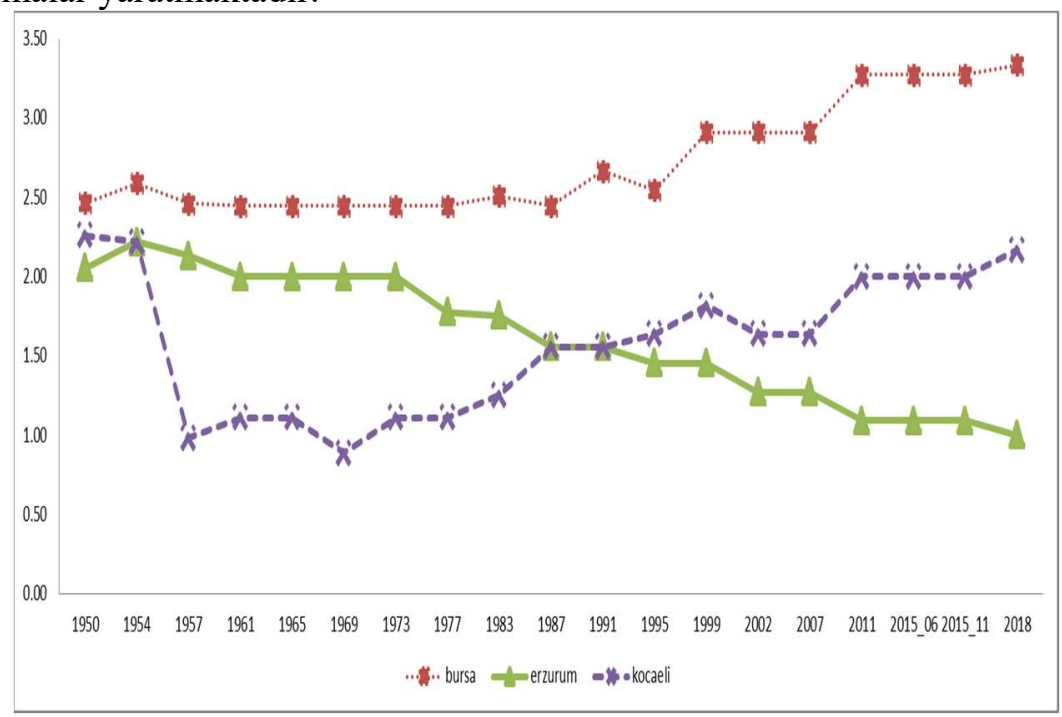

Şekil 1: Milletvekili Sayılarının Toplam İçindeki Payları

Şekil 1'de Bursa, Erzurum ve Kocaeli'nin 1950-2018 döneminde yapılan genel seçimler sonucunda çıkardıkları milletvekili sayılarının, meclisteki toplam milletvekili sayısı içindeki payları gösterilmektedir. Yıllar itibariyle Bursa ve Kocaeli'nin milletvekili sayılarında artı̧̧ trendi görülürken, Erzurum'da ise düşüş trendi göze çarpmaktadır. Şüphesiz bu durum, sosyo-ekonomik gerilemenin bir yansıması olduğu kadar, mecliste lobi kaybına bağlı olarak gerilemenin de bir nedenidir.

\section{Sonuç}

Gerileme süreci devam eden bölgeler açısından "genel anlamda bir Doğu ve özelde de Erzurum sorunu” bulunmaktadır. Erzurum özelinde yaşanan sorunların benzerini Trabzon, Van, Malatya, Elazı̆̆, Diyarbakır, Mardin, Sivas vb. iller özelinde de görmek mümkündür. Yanlış politikaların yol 
açtı̆g 1 giderek derinleşen bölgesel dengesizlik sorunu Doğunun boşalması ve Batının da kalabalıklaşmasını tetiklemiş̧ir. Ancak, son 100 yılda Türkiye'de uygulanan yanlış kamu politikalarına karşılık, bölgenin jeo-politik konumu mutlaka tarihte sahip olduğu rolüne kavuşacaktır. Sadece liberal devlet anlayışının tam gereği denebilecek biçimde pozitif dışsallıklar yaratacak altyapı yatırımları ile Doğu-Batı ve Kuzey-Güney bağlantılarının hem kara hem de demiryolu ile sağlıklı bir şekilde inşa edilmesine gerek duyulmaktadır.

Konuyla ilgili olarak A. T. Mahan ile H. J. Mackinder'in bakış açıları yol gösterici niteliktedir. Amiral Alfred T. Mahan'in dünya hakimiyeti kurmada, bütün tarih boyunca hâkim rolü, deniz gücünün oynadığını ortaya koyan tezi ve buna bağlı olarak sahili bulunmayan devletlerin, gücü ne olursa olsun, gerilemeye ve yıkılmaya mahkumdurlar ifadesi Türkiye özelinde üç tarafi denizlerle çevrili bir ülke için önemli bir mesaj niteliği taşımaktadır. Mahan’a göre kara baştanbaşa engel demektir, deniz ise açıklık ve kolaylık zeminidir. Dolayısıyla deniz avantajını iç kısımlara, yani kara ile bağlantılama noktası Türkiye için elzemdir. Diğer taraftan "Tarihin Coğrafi Mihveri” adlı eserinde Sir Halford J. Mackinder açısından yeni dönemin tabii kuvvet merkezi, dünyanın en büyük kara kitlesi, Avrupa ve Asya kıtalarının muazzam toprak sahası "dünya politikasının mihver bölgesi”dir şeklindeki tezi de dikkate değerdir. Mackinder'in kitabında sözünü ettiği iddialarını çok bilinen şu formül ile özetlemek mümkündür: Doğu Avrupa'ya hakim olan Merkez Bölgeye hakim olur: Merkez Bölgeye hakim olan Dünya adasına hakim olur: Dünya Adasına hakim olan Dünyaya hakim olur. Mackinder'de belirtilen iddialar özellikle karasal yükseltilerin önemli roller üstlendiğine dairdir (Downs, 2007). Gerek Mahan'ın, gerekse Mackinder'in ifadeleri dikkate alındığında, Doğu'nun boşalmasının önüne geçecek temel politikaların başında karasal geçiş noktalarını deniz ile buluşturacak yapılanma gelir. Dolayısıyla cari kara, demir ve hava yolunun rehabilitasyonu bu fonksiyona yardımcı olacağı gibi, özellikle demiryolunda hıza dayalı mekanizmanın Gürcistan ve İran bağlantısının kurulması önem arz edecektir.

Ayrıca sanayileşme ve kalkınma plansız ortaya çıkmaz, aksine bizde planlama adeta tasfiye edilmiş, böylece "iyi devlet" ve “iyi girişim” unsurunun farkındalığı kaybolmuştur. Bölgenin kurtuluşu şüphesiz ülkenin de kurtuluşu anlamına gelecektir; "hem orta gelir tuzağından styrılmak hem de Batının kalabalıklaşmasının önüne geçmek" için buna ihtiyaç bulunmaktadır.

Dolayısıyla bölgede yer alan başta üniversite ve belediyelerin karşılaştırmalı üstünlük yapısını dikkate alan öncü ya da inovatif yatırım yapmalarının örnek teşkil edeceği ve "bölge girişimcilerinin de daha çok imitasyona dayalı girişimde bulunma özellikleri” dikkate alındığında (bkz. Özkan vd., 2003; İrmiş ve Emsen, 2002), örnek yatırımlarla bölgesel canlanma etkileri ortaya çıkarılabileceği düşünülebilir. Zira Türkiye genelinde olduğu gibi bölgede de kentleşme sürecine bağlı olarak nasıl ki, “müteahhitler veya kafeler yaygınlaştı”ysa, ilk etapta bölgenin avantajlarını ortaya koyacak bir girdi-çıktı 
çalışmasıyla, avantajlı ve canlanma etkileri doğuracak alanlar tespit edilerek bu alanlarda yatırımlara gidilebilir.

Diğer taraftan özellikle "Batıda yığılan fiziki ve beşeri sermaye sahibi hemşerilerin bölgeye ilgisini harekete geçirecek ve böylece gerek dışarıdaki hemşerilerden, gerekse yerel girişimcilerden müteşekkil ortaklıklart tetikleyecek mekanizmalara ihtiyaç duyulmaktadır”. Dışarıdakilerin deneyimi ve içeridekilerin birikimini harmanlayacak mekanizmaların nasıl yaratılabileceği noktasında Sanayi ve Ticaret Odalarına önemli işler düştügü söylenebilir.

Aksi takdirde geri kalmışlık hem devam edecek hem de derinleşecektir ki, bunun yol açtığı psikolojiyi Çorum yöresine ait bir halk deyişi en iyi şekilde özetlemektedir: "Bu sene tarlaya bostan mi ekek, Osmanı mı everek, İstanbul'a mı göçek”.

\section{Kaynaklar}

Acemoğlu, D. ve Robinson, J. A. (2014), Ulusların Düşüşü: Güç, Zenginlik ve Yoksulluğun Kökenleri, (Çev. F. R. Velioğlu), İstanbul, DK Doğan Kitap. Aydın, A. (2008), İktisadi Açıdan Bölgesel Dengesizlik: Mardin İli Örneği, Elektronik Sosyal Bilimler Dergisi, 7 (24), 304-312.

Başel, H. (2007), Türkiye'de Nüfus Hareketlerinin ve İç Göçün Nedenleri, Sosyal Siyaset Konferansları Dergisi, 53, 515-542.

Chang, H.J. (2015), Sanayileşmenin Gizli Tarihi, (Çev E. Akçaoğlu), Ankara, Efil Yayinevi.

Coşkun, O. (2008), İç Göçler Açısından Erzurum İlinin Analizi, Doğu Coğrafya Dergisi, 20, 239-266.

Çatal, M. F. (2010), Devlet Teşvikleri ve Erzurum'da Tarihsel Bir Uygulama Örneği, Atatürk Üniversitesi İktisadi ve İdari Bilimler Dergisi, 24 (4), 289-296.

Çatalbaş, G. K. ve Yarar, Ö. (2015), Türkiye'deki Bölgeler Arası İç Göçü Etkileyen Faktörlerin Panel Veri Analizi İle Belirlenmesi, Alphanumeric Journal, 3 (1), 99-117.

Dinler, Z. (2005), Bölgesel İktisat, Bursa, Ekin Kitabevi Yayınları.

Downs, R. B. (2007), Dünyayı Değiştiren Kitaplar, (Çev. E. Güngör), Ankara, Ötüken Neşriyat

Ervak (1999), Erzurum İli Kalkınma Raporu (II), Erzurum, Erzurum Vakfi Yayınları No: 9.

Gerni, C., Emsen, Ö. S. ve Dölek, A. (1998), Erzurum İlinin Ekonomik Durumu, Cumhuriyetin 75. Y1linda Erzurum, ss: 1-17.

Gerni, C., Sarı, S., Sevinç, H. ve Emsen, Ö. S. (2015), Bölgesel Dengesizliklerin Giderilmesinde Yatırım Teşviklerinin Rolü ve Başarı Kriteri Olarak Yakınsama Analizleri: Türkiye Örneği, Uluslararası Avrasya Ekonomileri Konferans1, 9-11 Eylül 2015 - Kazan, Rusya, 311320. 
Günok, M. Z. (2018), Türkiye'de Bölgelerarası Gelişmişlik Farklarının Bir Yansıması Olarak İşsizlik Olgusu ve Van Örneği, Çalışma ve Toplum, 3, 1397-1434.

Güran, T. (2012), İktisat Tarihi, İstanbul, Der Yayınları.

Hampson, C. S. (1891), Report for The Years 1889-90 on the Trade of Erzeroum, Diplomatic and Consular Reports on Trade and Finance, Foreign Office 1891. Annual series. no- 980.

İrmiş, A. ve Emsen, Ö. S. (2002), İktisadi Gelişmede Girişimcilik: Denizli ve Erzurum Örneği, İstanbul, Beta Yayınları.

Kaynak, M. (2011), Kalkınma Iktisadl, Ankara, Gazi Kitapevi.

Kaplan, H. (2019), Türkiye'de Bölgesel Dengesizliklerin Giderilmesi ve Teşvik Tedbirlerinin Rolü ve Etkinliği, Hacettepe Üniversitesi Sosyal Bilimler Enstitüsü, Yaymlanmamış Yüksek Lisans Tezi.

Karaalp, H. S. ve Erdal, F. (2009), Türkiye'de İller Ve Bölgeler Arasında Gelir Farklı1ıkları: Bir Sigma Yakınsama Analizi, Uluslararası Davraz Kongresi, 24-27 Eylül 2009, Isparta, 27-39.

Kemal, Y., Yusufçuk Yusuf - Akçasazın Ağaları 2, Yapı Kredi Yayınları, İstanbul, 2015.

Küçükali, A. (2018), Akademisyenlerde Göç Etme Niyeti: Erzurum İli Örneği, HAK-IŞ Uluslararası Emek ve Toplum Dergisi, 7 (19), 588-608.

Küçükoğlu, M. (2005), Vergisel Teşviklerin Bölgesel Kalkınmadaki Rolü: Güneydoğu Anadolu Bölgesi Üzerine Uygulama, Uludağ Üniversitesi Sosyal Bilimler Enstitüsü, Yayımlanmamış Doktora Tezi.

Nişancı, M. ve Emsen, Ö. S. (2016), Mutlak ve Nisbi Kalkınma Bağlamında Erzincan ve TRA Bölge Ekonomisi Üzerine Bir Değerlendirme: Gelişme İçin Model Arayışları, Uluslararası Erzincan Sempozyumu, 28 Eylül-1 Ekim 2016, 615-627.

Özkan, Ş., Gündoğdu F., Emsen, Ö. S. ve Aksu H. (2003), Türkiye'de Girişimcilik ve Belirleyicileri: Marmara ve Doğu Anadolu Bölgesi Üzerine Bir Uygulama, Ankara Üniversitesi Siyasal Bilgiler Fakültesi Dergisi, 58 (4), 145-172.

Öztürk, L. (2012), Türkiye'de Bölgesel Eşitsizliğin Sektörel Dinamikleri: Bir Ayrıştırma Analizi, 1987-2001, Ege Akademik Bakış, 12 (2), 149-159.

Pamuk, Ş. (2014), Türkiye'nin 200 Ylllık İktisadi Tarihi, İstanbul, Türkiye İş Bankası Kültür Yayınları.

Recepoğlu, M. ve Değer, M. K. (2016), Türkiye'de Bölgesel Yatırım Teşviklerinin Bölgesel Ekonomik Büyüme Üzerine Etkisi: Düzey 2 Bölgeleri Üzerine Panel Veri Analizleri (2004-2011), Kastamonu Üniversitesi İktisadi ve İdari Bilimler Fakültesi Dergisi, 14 (4), 6-21.

Sarı, R. ve Güven, A. (2007), Kalkınmada Öncelikli Yöreler Uygulamasının İller Arası Gelir Dağılımı Üzerindeki Etkisi, ODTÜ Gelişme Dergisi, 34: 77-96. 
Il Düzeyinde Gerileme Süreci: Erzurum Örneğgi

Şahin, H. (2012), Türkiye Ekonomisi: Tarihsel Gelişimi-Bugünün Durumu, Bursa, Ezgi Kitabevi.

Şahin, M. ve Uysal, Ö. (2011), Bölgesel Kalkınma Çerçevesinde Yatırım Teşviklerinin Shift-Share Analizi, Maliye Dergisi, 160, 111-138.

Tanpınar, A. H. (2004), Beş Şehir, İstanbul, Dergah Yayınları.

TUIK, (2019), Türkiye İstatistiki Göstergeleri, Ankara,.

World Bank, (2019), World Development Indicators, Washington DC.

Yalçın, S. (2017), Saklı Seçilmişler, İstanbul, Kırmızı Kedi Yayınevi. 